\title{
Obituaries
}

\section{MICHAEL NORMAN WOOD}

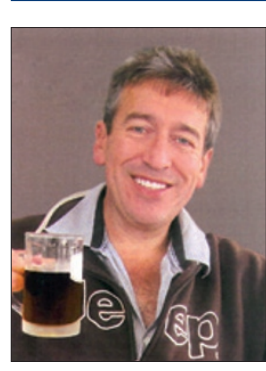

Michael Norman

Wood (Woody)

from Silsoe, Bed-

fordshire passed

away on 21 May

2013 in Houston

Texas, aged 49.

Michael was

born in Cape Town,

South Africa on 2 August 1963. He completed his schooling in Cape Town and went on to study dentistry at the University of Stellenbosch. He was called up for two years of military service in which he completed his honours degree, BChD Hons (Stel).

Michael came to the UK in 1991 and worked as a dentist in London. In 1996 he acquired Leagrave Dental Anaesthetic Clinic.

He was dedicated to dentistry and went on to study for various postgraduate diplomas, including, to name but a few, FDS RCS (Ed), MFGDP, MFD RCS(Ire), M SND RCS(Ed).

Michael did his master's degree in conscious sedation for patients with special needs. He studied implantology for four years at the University of Lille in France getting DUI (Lille) and became a Fellow of RCS Edinburgh.

Michael loved sport, particularly rugby and cricket, and travelling and hiking. In February 2013 he climbed Kilimanjaro to raise money for Keech Cottage Children's Hospice.

He is, and will be, sadly and greatly missed by his wife, Greer and his three children, Kathrin, Dylan and Aiden, his extended family, his colleagues, his patients, staff and all others who came to know him.

\section{GORDON DICKSON}

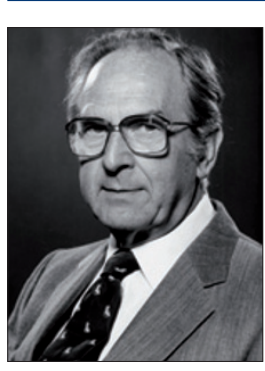

Gordon Dickson was born in Yorkshire on 15 April 1920. He qualified in dentistry in Sheffield and served in the Royal Naval Volunteer Reserve during the Second World War. Developing an interest in orthodontics, he was the second consultant orthodontist to be appointed after the formation of the National Health Service in 1948. Initially in Birmingham, he moved to the south coast to establish a new department at the Royal Portsmouth Hospital in 1957.

Gordon developed a close working relationship with local colleagues and at an early stage established an innovative, part-time training programme and support service for dental practitioners undertaking orthodontic treatment. He was the author of Orthodontics in general dental practice and co-authored with Albert Wheatley, his technician, An atlas of removable orthodontic appliances. These became standard texts and were translated into several languages. He was active in the British Dental Association and served as chairman of the Portsmouth Section. He was later elected a life member of the Association.

He was invited to deliver the Northcroft Lecture of the British Society for the Study of Orthodontics in 1969 and served as president of the Society. He was elected as a member the Board of the Faculty of Dental Surgery of the Royal College of Surgeons of England in 1972 and vice-dean in 1978.
Obituaries should be submitted by email to Laura Pacey at I.pacey@nature.com.

All submitted obituaries should be 350 words maximum in length (apart from obituaries for past presidents of the BDA where the length should be $700-800$ words).

Content of the obituary is down to the individual author, and the approval of the family should be given for the obituary prior to submission to the $B D J$.

At Portsmouth his personal qualities earned the respect of his consultant colleagues and he was elected chairman of medical staff. He retired from clinical practice in 1985.

Outside a distinguished career in dentistry, he had a love of music and combined his interests in natural history and photography. He received an award from the British Mycological Society in 1987 for organising a mycological survey in the Amazonian rain forest in Ecuador. In 1996 he coauthored The fungi of the new forest - a mycota, which became a definitive reference book.

Gordon was held in great affection by those who knew him. He died in Hampshire on 1 August 2013 in his 94th year. His wife Joy predeceased him but he is survived by his sons Richard and Robert, his daughter Diana and four grandchildren.

David Barnard 